\title{
Improve the Effectiveness of Practical Teaching of Ideological and Political Theories Course Based on Science and Technology Competition for College Students
}

\author{
Shen Yongzhen \\ Xi'an Peihua University, Xi’an, Shaanxi, China
}

\begin{abstract}
Keywords: college students; science and technology competition; ideological and political theories course; effectiveness
\end{abstract}

\begin{abstract}
This paper focuses on the science and technology competition for college students, regards the practical teaching as the fusion point of theory and practice, knowledge and ability, creates an open platform for practical teaching, widens the cooperation range of colleges and enterprises, actively advances the social practice activities which can be chosen free by students, and integrates resources of practical teaching base, adopts the social practice teaching mode of "project +competition" to improve the comprehensive quality of students, encourages and guides college students to participate in science and technology competition actively, and learn to analyze and solve problems with the basic principles of Marxism, and pays attention to cultivate the ability of knowledge application, the operation, solving problems, and innovation, the awareness of benign competition, the team-work spirit, the ability of adapting to the workplace and etc. to improve the effectiveness of practical teaching of ideological and political theories course.
\end{abstract}

Put emphasis on the science and technology competition for college students, and focus on cultivating the innovation awareness, practice ability, competition and responsibility awareness and the team-work spirit of students is the dialectical unity of times, subjectivity and internality of ideological and political education in colleges. In recent years, various colleges put forward the cultivating objective of "advanced special talents with innovation and practice ability" according to Higher Education Act, strengthen continuously the reform and exploration of practical teaching, take the ideological and political education as the fundamental point of talent cultivation, practical teaching as the fusion point of theory and practice, knowledge and ability, cultivate comprehensively the innovation spirit and practical ability of students from the science and technology competition and other practical activities, thus enhance the persuasive power, attraction and inspiration of ideological and political theories course and improve the effectiveness.

\section{The feasibility of combination of practical teaching of ideological and political theories course and science and technology competition for college students}

\subsection{The significance of science and technology competition for college students}

Science and technology competition for college students refers to various science and technology competition activities held on the basis of classroom teaching, which generally guide students to discover, analyze and solve problems with one or several subjects knowledge, assess effects of classroom learning, improve the innovation and application ability of students, cultivate talents in practice, accomplish the unity of knowing and doing and enhance moral and legal accomplishment of students. Rich competition activities with different types and levels, on one hand, cultivate the innovative passion, operation ability, the awareness of benign competition and the team-work spirit of students, on the other hand, mobilize the enthusiasm of learning and create an aspiring learning atmosphere in colleges. And as for college students, they can learn and practice, and obtain relevant certificates or award credits at the same time, which is beneficial to graduation and satisfying employment.

Advisors of ideological and political theories course, under the guidance of competition, on one 
hand, improve their professional skills of related competition programs and enrich teaching experience of this course; on the other hand, help students enhance humanity quality and active initiative of learning, learn to communicate and cooperate with each other in competition, learn the benign competition, establish proper attitude toward learning, and develop good academic atmosphere, form science and technology competition culture and give new connotations to campus culture.

\subsection{The influence of science and technology competition on practical teaching of ideological and political theories course}

By virtue of science and technology competition, students can apply theory knowledge learned from classroom to actual operation and cultivate the innovation ability. The innovative education for college students, as the core of quality-oriented education for colleges and universities, takes the cultivation of innovation spirit and creation ability of college students as basic value orientation, and it is a kind of education mode of cultivating innovative talents with better thinking quality, unique personality and aggressive spirit based on the requirements of integrated talents in an all-round way from the society. To hold science and technology competition for college students is to guide students to combine theory knowledge and reality problems in the manner of competition based on classroom teaching and independent learning, and obtain innovative results by discovering, designing and solving problems independently and it is an effective way to implement innovative education for college students.

Based on science and technology competition, the practice of ideological and political theories course can transform teaching material system to practical teaching system, encourage and guide students to pay attention to the society and people livelihood, participate in social practice consciously, learn new information and new project of all aspects and all fields in economic and social development, stimulate innovative inspiration, carry out innovative researches, actively take participation in science and technology competition, improve innovation ability, and gain innovative results. Therefore, the effectiveness of ideological and political theories course education can be accomplished in science and technology competition for college students.

\section{Conditions of carrying out practical teaching of ideological and political theories course with the aid of science and technology competition}

\subsection{The construction of system of ideological and political theories course teacher doubling as academic advisor}

In recent years, colleges and universities carry out various reforms, and some have established the system of ideological and political theories course teacher doubling as academic advisor, which provides the condition for the practical teaching of ideological and political theories course in the form of science and technology competition for college students. Teachers guide students to learn theory knowledge and conduct social practice, which has become the common work for them because of the system. When guiding students to participate in science and technology competition like innovation and venture competition, social practice and social survey, academic advisor conclude that it is necessary and feasible to carry out practical teaching of this course with the aid of science and technology competition.

\subsection{Colleges require the guidance of teachers in science and technology competition}

Colleges actively encourages teachers of ideological and political theories course to guide students in competition activities at all levels, to which colleges pay much attention. In order to improve the level of competition, strengthen the guiding team, colleges motivate to form a guiding team which is comprised of interdisciplinary teachers, and teachers of ideological and political theories course is the core power in the team. For instance, teachers of this course take participation in initiating students to attend competition, holding competition tutorial class, guiding the class on intensive training before the competition and tutorial class during the competition, and offer 
students who attend competition psychological counseling before and after competition, so as to lead them to keep calm for competition and keep the spirit of team-work and cooperation and the awareness of competition. And they can give material reward and moral encouragement to students who won prizes in competition to stimulate their passion for science and technology competition.

\subsection{Teachers of the course cultivating the innovative spirit of science and technology of students}

In order to cultivate the innovative spirit of science and technology, teachers of the course, in the classroom, establish the mechanism of actual practice motivating teaching reform and create the practical teaching mode. With the aid of knowledge contest, discussion on topic issues, debate competition, The Reader, speech competition, scene play, micro film and etc., students learn and improves the innovation ability, critical skills and the ability of professionalism and cooperation. Sometimes, teachers introduce a large number of science and technology competition cases to guide students to find out the reason of the failure, give a representative speech, discuss startup project, and finish the proposal after school to cultivate the innovatiion spirit of students and improve the awareness of responsibility in team-work by combining actual cases and theories in classrooms.

Outside class, on campus, teachers always hold teaching salon activities with rich contents, innovation design contest, micro video contest, speech contest, debate contest, design works contest, technological innovation, Maker Education, law teahouse saloon exchanges and etc. to cultivate the ability of independence investigation, professionalism and cooperation and awareness of science and technology competition of students to become a responsible man with ideas and skills. Outside the campus, teachers often encourage students to take part in various kinds of social activities for public good and research activities, or lead them to social practices outside the school. And teachers require them involved to write research report after these activities to be reviewed carefully to train the ability of practice and serving the society and the awareness of innovation and creation and improve the competence level of students in science and technology competition.

\section{The approaches of practical teaching of ideological and political theories course with the aid of science and technology competition}

\subsection{Establish the platform, create the team}

To establish the platform of science and technology competition is a good approach to improve the effectiveness of practical teaching of the course, which train the capacity for scientific research, innovation and practice based on all kinds of competitions about ideological and political theories course, and with the springboard of competitions in colleges, the media of competitions in province, and the aim of competitions in the whole country.

Each year, from the first classroom, second classroom to third classroom, teachers hold such various competition activities as innovation design contest, startup plan contest, advertising design contest and etc. selected from the school to province to promote continuously the platform construction of science and technology competition of ideological and political theories course.

Table 1 Team members and division of work in the team of science and technology competition

\begin{tabular}{|l|l|}
\hline Team members & Division of work \\
\hline Special experts & $\begin{array}{l}\text { Answer questions for program team, offer guidance and suggestions on } \\
\text { key problems and technological difficulties }\end{array}$ \\
\hline Guiding advisors & $\begin{array}{l}\text { Offer all-round guidance of different perspectives in science and } \\
\text { technology competition }\end{array}$ \\
\hline Team students & $\begin{array}{l}\text { According to the principle of complementing each other's advantages, } \\
\text { make responsibilities clear, discuss technological plans together and } \\
\text { accomplish works of science and technology competition. }\end{array}$ \\
\hline
\end{tabular}

It is very important to create a team of science and technology competition. The strength of cooperation in an excellent team is powerful and the work efficiency can be enhanced immeasurably. Members of each team are grouped by the team leader. When group the team, 
members can be chosen according to projects in the competition, teachers or experts provide guidance and suggestions on members selected cross the disciplines or from the same discipline and inappropriate members can be changed at any time. In science and technology competition, each member should take their own responsibility, discuss problems together or ask guidance from teachers. Guiding advisors should follow up the process of competition and offer all-round guidance of different perspectives. Special experts, as the strong support of science and technology team, answer questions for program team, offer guidance and suggestions on key problems and technological difficulties to help team members get through problems and difficulties.

\subsection{Teachers guide the competition to improve the teaching effectiveness of the course}

Teachers of ideological and political theories course train the innovation ability of students, which is an important part of contents of the course, and guiding the competition is an important method.

In fact, science and technological competition is the significant practice of the cultivation of team-work for students, and the process of attending the competition is the process of combing the independent studying of students and the guidance of teachers, from topic selection, project design, process and production, debugging to conclusion. In general, science and technological works are made on the basis of professional knowledge, teachers provide guidance from the macro perspective, combining theory and practice, teach methods to improve the ability of analyzing and solving problems, and lead students to grasp techniques with professional advisors to finish the works.

Table 2 Method, knowledge, skills, spirit and ability required by teachers in the cultivation

\begin{tabular}{|l|}
\hline Method, knowledge, skills, spirit and ability required by teachers in the cultivation \\
\hline Perspectives of topic selection \\
\hline Scientific research methodology \\
\hline Professional knowledge required for topic selection \\
\hline Computing method and capabilities in practice \\
\hline $\begin{array}{l}\text { Techniques such as document writing, PPT production, video presentation production } \\
\text { required in the competition }\end{array}$ \\
\hline Language competence and critical thinking required in the oral defense of works \\
\hline Interests, curiosity, critical thinking and design thinking required in work design \\
\hline The spirit of professionalism, cooperation, craftsmanship, and perseverance \\
\hline The ability of discovering, analyzing and solving problems \\
\hline
\end{tabular}

\subsection{To innovate social practice mode of the course with the driving force of science and technological competition}

With the driving force of science and technological competition, a fine, scientific, and long-term working mechanism is established, and a complete set of incentive mechanism for science and technology competition is created considering the subject characteristics of the school to form a path of training innovative talents with science and technology competition as a platform, and to explore an innovative teaching mode with the combination and promotion of theory and practice.

\subsubsection{To set up an open platform of practical teaching}

In order to realize the role of science and technology competition in the cultivation of innovative talents, and meet the requirements of independent studying and improvement of college students, college should improve the open platform of practical teaching. The self-selected laboratories shall be open with an appointment. Platforms with network access shall be full open so that students can use resources of online platform at any time and search for materials required in competition, in this way, the enthusiasm of students for science and technology competition can be promoted and the ability of innovation and creation can be enhanced.

\subsubsection{To expand the scope of cooperation between college and enterprise}

The coalition of college and enterprise is a significant method for the education reform and 
development, which is an important platform to provide practical teaching and train the innovative ability for students. At present, the cooperation between college and enterprise is only carried out in some schools or some majors, which is not beneficial to realize the interaction between college and enterprise in the whole college, the unity of learning and doing, and the joint of production and education. Therefore, it is necessary for college to expand the scope of cooperation between college and enterprise. In this way, "practice with real program, operation with real equipment and train in real environment" can be achieved in the whole college. Projects in science and technological competition are mainly designed according to problems existing in enterprises to enhance the ability of operation, analyzing and solving problems, the innovative spirit of students and realize the unity of knowing and doing.

\subsubsection{To promote social practice activities}

Each college shall encourage students to take part in social practice activities where the innovation of students can be inspired to select the topic. Firstly, social investigations. College students can conduct social investigations in the period of summer and winter holidays and carry out researches on some issues according to the investigations. Secondly, volunteer service. Some college students often take part in public benefit activities. For instance, students from medical college participate in the Red Cross and some offer volunteer services in nursing home. Some college students can select the topic for the competition based on the thinking on problems in their volunteer activities. Thirdly, science and technological and cultural activities. Colleges can hold science and technological and cultural activities where various kinds of innovative works and creation ideas are presented. Students need to actively participate in the work creation and learn from works of other students to improve their professional knowledge and capabilities.

Each college shall actively integrate resources of practical teaching bases, such as the program under which officials, doctors, scientist and college students go to the countryside to spread scientific and literacy knowledge and offer medical service to farmers, so as to form the pattern of the integration of revolutionary tradition education base, internship base, quality education base and social service practice, taking the experience gained at one unit and popularizing it in a whole area to improve the comprehensive quality of students.

\subsection{4 "Project+ competition" to improve the comprehensive quality of students.}

Projects are conducted to serve the society in the exploration of practical teaching and related researches of the ideological and political theories course, which is helpful for students to obtain the victory in science and technological competition by virtue of its practical characteristics. College students improve their comprehensive quality in science and technological competitions, learn to analyze and solve problems with basic principles of Marxism, and enhances the capabilities of applying knowledge, analyzing and solving problems, innovation and adaptive ability to real workplace.

In the activity of "project+ competition", students not only understand the new ideas, new guidelines, and new strategies of China, but also strengthen the confidence, cultural confidence, institutional self-confidence, and theoretical confidence in the socialist road of China. It also creates a new effective method for the practice of ideological and political theories course, strengthens the persuasive power, attraction and appealing of the course, and enhances the effectiveness of practical teaching of ideological and political theories course.

\section{References}

[1] Zhang Lijun, Wang Dongxiao, Tang Yi, Li Shuxuan, Hao Qun, Zhang Zhonglian. Exploration of extracurricular practical teaching mode based on "Curriculum" to guide students in science and technological competition [J]. Experimental Technology and Management, 2016,33(03):217-220.

[2] Lan Rongcong. Exploration of Cultivation Mode of Innovative Ability Based on Science and Technology Competition- Example of Bafang Logistics College of Fuzhou University [J]. Journal of 
Innovation and Enterprise Education, 2014,5(01):21-24.

[3] Li Ning. Research on the Scientific and Technological Competitions Cultivate Undergraduate Innovative Ability [D]. Hunan University of Science and Technology, 2013.

[4] Guo Lingling, Fu Yu, Su Dongna, Yin Xiaozhe. Study on Practical Teaching Mode Based on Competition [J]. Education Modernization, 2017,4(34):31-32+36.

[5] Sun Shiming, Liu Xinping, Zhang Xiaodong. Practical Teaching System of Internet of Things Engineering Based on Competition [J]. Computer Education, 2016, (01):153-156. 